\title{
Development of Indonesian Correspondence Teaching Materials Based on High Order Thinking Skills (HOTS) to Improve Students Competency Towards the Revolution 4.0 Era
}

\author{
Ellys Siregar ${ }^{1, *}$, Efendi Napitupulu ${ }^{1}$, Sri Mutmainnah ${ }^{1}$, Rotua SP Simanullang ${ }^{1}$ \\ ${ }^{1}$ Universitas Negeri Medan \\ *Corresponding author.Email: ellyssiregaradp@gmail.com
}

\begin{abstract}
Teaching materials are all forms of material that are designed and arranged systematically to enable students to learn independently and be adapted to the applied curriculum. This study aims of this research to design Indonesian Correspondence teaching materials that can are expected to improve students' high order thinking skills Office Administration Education students. Teaching materials designed are validated by experts in terms of content, language, and development design, then tested on students according to the stages. The research design used the ADDIE research and development model. This model is suitable to be applied to the development of teaching materials because the stages are systematic. The instruments in this study were collected through questionnaires, observation sheets for students who took Indonesian Correspondence courses in the odd semester of 2020/2021. Based on the results of trials conducted in class, it was found that the teaching materials that were designed were quite good because they met the criteria and characteristics of the course and students. Based on the student response questionnaire, it was found that student responses were very positive (98.33). Teaching materials meet the criteria of being effective, $65 \%$ of students get completeness scores and 35\% more get 90 points in the aspect of mastery of the material. The data in this research were analyzed using a qualitative descriptive method. The results obtained indicate that the teaching materials designed and developed are effective enough to improve students' higher order thinking skills (HOTS) in the Indonesian Correspondence course.
\end{abstract}

Keywords: Teaching materials, Indonesian Correspondence, High Order Thinking

\section{INTRODUCTION}

Education is held as a process to develop the full potential of students [12]. In educational activities, there are activities to teach students by designing, implementing and evaluating activities systematically all the elements in it [6]. Through educational activities, students are expected to be able to master competencies that will lead them to become better people, even fulfil the rules of eligibility to be followed in social life In accordance with the objectives of Indonesian National education as stated in the National Education System Law

No. 20 of 2003, namely to develop the potential of students to become human beings who believe and are responsible to God Almighty, noble, healthy, knowledgeable, competent, independent and become a democratic and responsible citizen [4] Along with the progress of the times, marked by revolutions in all fields, demanding changes in every aspect of life, including in the field of education. In the world of education, these changes require students to become qualified human resources, ready to compete in the global world and have competence in their fields to be able to solve complete problems that are often found in society.

To respond to these changes the teacher plays a very important role, the teacher acts as a facilitator or mediator and designer so that students are active in developing high-level thinking skills [15]. The ability to think at a high level (high order thinking) is a thinking skill that requires students to think critically, creatively, analytically on information and data in solving information. Students in higher education should apply higher order thinking patterns [5].

The development of teaching materials containing HOTS needs to be developed due to the times, the needs 
and demands of today's society which are very complex. The development of teaching materials has the aim of providing teaching materials that are in accordance with the demands of the curriculum by taking into account the needs of students, namely teaching materials that are in accordance with the characteristics and settings or the social environment of students. Helping students in obtaining alternative teaching materials in addition to textbooks that are sometimes difficult to obtain, as well as making it easier for teachers to carry out learning [4].

Learning with a scientific approach can improve students in higher-order thinking (Higher Order Thinking Skills / HOTS), because the student learning process goes through scientific stages, namely observing, asking questions, gathering information, associating, and communicating. HOTS is an internal process that occurs within a person which is characterized by the following characteristics: (1) It involves more than one correct answer; (2) Talking about the level of understanding; (3) Characterized by complex tasks; and (4) Free of content as well as content-related. Costa shares high-order thinking skills on problem solving, decision making, critical thinking and creative thinking.

Problem solving is a process used to solve problems. One definition of problem solving is a process that consists of many steps to solve a problem. A person will be able to solve a problem if he finds a connection between his past experiences (schemes) and the problem he is currently facing and then acts to solve it.

The ability to solvess problems according to Gagne is the highest learning outcome, because when a Higher Order Thinking Skills-based learning manages to solve a problem, then someone has achieved two things at once, namely the answer to the problem (knowledge) and the way the problem is solved (process) [8]

In accordance with the above study, this research is considered quite important and urgent considering that students who are currently taking Indonesian Correspondence courses when they have completed their studies and later enter the community, both as teachers and as secretaries, need to prepare themselves from college to face the changing times. which is so fast and coupled with the demands to be able to complete the task and job. The reality in the field today, there are still many students who are less able to achieve the maximum learning outcomes as expected.

In order to form graduates who are competent and able to compete in the 4.0 era in the field of One Correspondence, it is necessary to design teaching materials that present examples and exercises based on high order thinking skills. With teaching materials which are HOTS-based teaching materials development plans, it is hoped that students will be able to increase their competence in their scientific fields, especially in the Indonesian Correspondence field, so that they have competences and skills in global competition. HOTS as critical thinking is a flow of reason (reasonable) that is focused on what is believed or done, which is a general ability that is often described as a teaching goal. In this case it can be interpreted as the ability of students to apply wise decisions or produce criticism with strong arguments.

Learning with a scientific approach can improve students in higher-order thinking (Higher Order Thinking Skills / HOTS), because the student learning process goes through scientific stages, namely observing, asking questions, gathering information, associating, and communicating. The ability to think critically can be empowered by understanding aspects related to the conception of critical thinking.

When a person applies critical thinking skills, he will try to build arguments or reasons that fit the context, deduce logically as well as induce facts to make generalizations (conclusions) related to interpretations of questions and finally choose possible alternative solutions. The HOTS characteristics are: (1) measuring higher order thinking skills, minimizing aspects of memory or knowledge, (2) based on contextual problems, (3) interesting stimuli, and (4) not routine. The characteristics of higher order thinking include the ability to find, analyze, create new methods, reflect, predict, argue, and make the right decisions.

The dimensions of HOTS cognitive processes according to Anderson \& Krathwohl include creating, evaluating, and analyzing [2]. Creating, namely creating your own ideas / ideas. The verbs that are usually used to indicate to create are construct, design, create, develop, write, formulate. Evaluating is making your own decisions. Verbs that are commonly used to indicate evaluation such as assess, argue, decide, vote, and support. Analyzing, namely specifying aspects / elements, verbs: comparing, examining, criticizing.

Based on the description above, it can be concluded that HOTS is an internal process that occurs within a person which is characterized by the following characteristics: (1) It involves more than one correct answer; (2) Talking about the level of understanding; (3) Characterized by complex tasks; and (4) Free of content as well as content-related. Costa shares high-order thinking skills on problem solving, decision making, critical thinking and creative thinking [14].

\section{RESEARCH METHOD}

In this research, the method used is the Research and Development (R \& D) method. The basis for choosing this method is because the researcher wants to develop teaching materials. Research is defined as a systematic study of complete scientific knowledge or understanding of the subject under study. 
This research is classified as basic or applied according to the goals of the sponsor. Development is defined as the systematic application of knowledge or understanding, directed at the production of useful materials, devices, and systems or methods, including design, development and improvement of priorities, as well as new processes to meet certain requirements. In simple terms, R\&D can be defined as a research method that is deliberately, systematically, aimed / directed to find, formulate, improve, develop, produce, test the effectiveness of products, models, methods / strategies / methods, certain superior, new, procedural services. effective, efficient, productive, and meaningful. Research and development is a process of developing educational devices carried out through a series of research using various methods in a cycle that passes through various stages.

Based on the definition above, it can be concluded that Research and Development or research and development is a research method used to produce and develop certain products with new innovations that are preceded by a testing or validation stage. The author tries to develop a teaching material. For this reason, validation of the teaching material is required. $R \& D$ is a research method that can be used to validate these teaching materials.

This is in accordance with the expression Borg and Gall at the beginning of the previous paragraph which states that $\mathrm{R} \& \mathrm{D}$ is also used to validate the product being developed. In this case the researcher develops teaching materials. It is a development of existing previous teaching materials.

The development of correspondence teaching materials is expected to bring novelty, excellence, effectiveness and efficiency. This reason also underlies the author using the R\&D method. $R \& D$ is intended to find novelty and excellence in terms of effectiveness, efficiency and productivity. The procedure used in this development research is to apply the ADDIE procedure. This model consists of several main stages, namely (A) analysis, (D) design, (D) development, (I) implementation, and evaluation(E).

\subsection{Analysis}

Analysis is the first step or stage in the ADDIE procedure. Analysis is used to find ideas and objectives to be achieved. In this stage the authors collect information through several sources such as literature reviews, direct observation and interviews.In this process the researcher tries to find the problems that exist in Indonesian Correspondence learning. First, the researcher tries to analyze the potential, the researcher looks at the teaching materials that have been used but has not included High Order Thinking-based assessments, while the expected competency demands of the current generation are the generation who are.

The two authors analyzed the problems that occurred in correspondence learning, from direct observation it was found that students who took the Correspondence course did not understand and master the material combined with the hots assessment. This happened because so far there was no teaching material that was enriched with hots-based assessments. Furthermore, at the analysis stage, it is added with literature review, namely theories that can be used as guidelines in an effort to improve and solve the underlying problem solving, including the definition of teaching materials. The alternative design of teaching materials designed and developed by researchers is a teaching material accompanied by a hots-based assessment instrument. The teaching materials are designed to improve students' hot thinking skills. So that it is expected to be able to improve the higher-level thinking skills of office administration education.

\subsection{Development}

Based on the problems that have been analyzed in Indonesian Correspondence learning. Then the next activity is to compile and design teaching materials. This is the basis for the development of Indonesian correspondence teaching materials. The steps in making Indonesian correspondence teaching materials are:

\subsubsection{Making Indonesian correspondence teaching materials)}

The steps taken by the researcher to make Indonesian correspondence teaching materials consisted of several steps, including: 1) determining the material or content of the book, 2) drawing and designing the cover, 3) writing the contents of the book, 4) making examples and evaluation instruments based on hots, 5) printing Indonesian correspondence teaching materials.

\subsubsection{Guidance and Assessment with course lecturers.}

The Indonesian correspondence teaching materials that have been made are then guided and assessed by the course lecturers. In this stage, the developed Indonesian correspondence teaching materials will receive suggestions and criticisms from experts or experts to be fixed, or declared appropriate. If the Indonesian correspondence teaching material has been declared appropriate, it can be continued for validation by media experts and material experts.

\subsubsection{Validation by Media and Material Experts}

Those who become media experts are lecturers who are competent in the field of learning media, while 
material experts are people who have competence in the field of Indonesian Correspondence learning materials. After the Indonesian correspondence teaching material was declared feasible by the subject lecturer, the teaching material was then validated by a validator, namely media experts and material experts. Media experts will assess Indonesian correspondence teaching materials by giving scores according to the assessment rubric, as well as material experts who will give grades according to the assessment rubric. Furthermore, the two experts will also provide suggestions in the form of input for improving the designed teaching materials. The suggestions from the two experts will be followed up, so that the teaching materials are declared suitable for use.

\subsection{Implementation}

The implementation of designed Indonesian correspondence teaching materials is carried out in the Office Administration Study Program of the Faculty of Economics with students taking Indonesian Correspondence courses. Furthermore, the implementation of this teaching material is also aimed at improving the high-level thinking skills of Office Administration students. At the implementation stage, this activity aims to obtain a valid and good design of Indonesian correspondence teaching materials. Product revisions are carried out by researchers periodically if the design has not reached the expected valid level. The party who plays an important role determines whether the design needs to be revised or is good and feasible to be implemented. Indonesian correspondence teaching materials that have been revised or improved are then applied to the trial class.

\subsection{Evaluation}

The last stage of the model used is the evaluation stage. In the evaluation stage carried out for Indonesian correspondence teaching materials, it aims to improve the product designed after going through the previous stage. Evaluation includes product improvements obtained from suggestions on questionnaires given to media experts and material experts (subject lecturers), then researchers can improve them. To see whether the designed Indonesian correspondence teaching material is effective or not and the student's interest in the teaching material, it can be seen from the results of the student response questionnaire and the distributed observation sheet. For development research, the research subjects of the quality of HOTS-based Indonesian correspondence teaching materials were three experts, namely media and material experts and from the responses of Office Administration Education students.

\section{RESULTS AND DISCUSSION}

The research carried out is development research (Research and Development) to produce products in the form of hots-based correspondence teaching materials which are tested on limited trials. Development is carried out after making prior observations, to determine the extent to which the instrument has been used as long as it can measure thinking ability. high level student. The observation took place combined with unstructured interviews with lecturers and questionnaire responses to students, this interview only provides questions without preparing answers and a response questionnaire for students contains several questions by preparing yes or no answer choices. So in this observation only listens to the opinions obtained from the lecturers and the results of the student responses questionnaire.

At the observation stage, the sample consisted of 30 students. The targets of the development of Indonesian Correspondence teaching materials are lecturers who join the group of lecturers in the field of Indonesian correspondence studies and students of office administration education, where the results of the interview show that the existing teaching materials do not contain hots-based evaluation instruments.

The results of interviews and student responses, this study aims to improve students' higher-order thinking skills so that the quality and quality of graduates will be better. In its development, teaching materials need to be validated by experts before being tested to determine their feasibility.

Validation consists of two experts, namely media validation and material validation. After the teaching material is validated and declared fit for use in the learning process. Then the correspondence teaching materials were tried out on students to see their responses. This trial was conducted in the Office Administration Education Study Program.

The results of the validation obtained from media experts, obtained the following data 1) at validation I, the ideal level of teaching materials for Indonesian Correspondence was $85 \%$ with input from Media Experts, namely the images contained in teaching materials must be adjusted to the needs not too big or too small and teaching materials already worth testing.

While the results obtained from the material expert validation, the following data were obtained the results of the first validation level of the ideality of correspondence teaching materials were $60 \%$ with input, namely teaching materials were not systematic and ordered according to the needs of teaching materials so that there must be some revisions of material and evaluation instruments in activities student learning. Therefore, a second revision and validation was carried out 
In the second validation, the ideal level of Indonesian correspondence teaching materials after being revised reached $75 \%$ with input from material experts, namely that some material could be streamlined and hots-based evaluation instruments were added. Therefore, a third revision and validation was carried out

In the third validation, the ideal level of teaching materials that was designed had reached $80 \%$. So that the teaching material is suitable for use. Meanwhile, the results of the media expert validation from the lecturers, obtained data where the ideal level of the teaching materials developed was $85 \%$. While the results of material validation from lecturers, obtained data where the ideal level of correspondence teaching materials reached $95 \%$ with comments, namely the teaching materials were good and arranged systematically and were worthy of being tested.

After validating and revising the developed teaching materials, it is found that appropriate teaching materials are used to improve students' higher order thinking skills. Next is the pre-test and post-test questions when learning is carried out. Test the questions using the $\mathrm{N}$-gain formula. The results of the gain analysis showed that there were 25 people with high criteria or gain interval $\geqslant$ 0.7 . Medium gain criteria or gain interval $0.3 \leqslant \mathrm{~g}<0.7$ for 12 students. So overall this research shows a gain with high criteria

Based on the results of the responses of 30 of the office administration education study program students to the teaching materials developed, the average score of the percentage of student responses is $95 \%$, it turns out that learning using the developed teaching materials can improve students' higher order thinking skills. The results of the maritime development research carried out on the HOTS-based Indonesian Correspondence course include: 1) HOTS-based worksheets and instruments; 2) HOTSbased learning materials. The designed worksheets are then used to help students understand the teaching material accompanied by an assessment instrument based on high order thinking skills. Worksheets or evaluation instruments developed by adopting problem-based learning steps which include: 1) problem orientation; 2) learning organization; 3) individual or group investigations; 4) development and presentation of problem-solving results; 5) analysis and evaluation of the problem-solving process.

Teaching materials designed include: 1) learning theory in learning; 2) basic concepts of learning strategies; 3) 21st century learning strategies; 4) learning approach; 5) learning methods and techniques; 6) learning model; 7) factory teaching; 8) strengthening character education. The evaluation instruments designed include: 1) hots-based assessment instruments; and 2) assessment guidelines.

\section{CONCLUSION}

The results of the analysis carried out on research and development data on Indonesian Correspondence teaching materials can be drawn as follows: (1) Development of Indonesian Correspondence teaching materials, namely teaching materials developed from the KKNI College curriculum. (2) The appropriateness of Indonesian Correspondence teaching materials is validated and assessed by experts both in terms of content feasibility, language aspects, media aspects, while for the readability and usability of Indonesian Correspondence teaching materials, a number of office students were tested with results in good categories.

\section{REFERENCES}

[1] Ali M., Aplikasi Pengembangan Kurikulum Tingkat Satuan Pendidikan dan Bahan Ajar dalam Pendidikan Islam, (Jakarta: Rajawali Pers, 2012, hlm. 128.

[2] Anderson, L.W., dan Krathwohl, D.R., A Taxonomy for Learning, Teaching, and Assesing; A revision of Bloom's Taxonomy of Education Objectives. New York: Addison Wesley Lonman Inc, 2001

[3] Budiaman. Z.., The Influence of Learning Strategis and Style of Thought on The Ability of Students to Solve Environmental Problems, XVII (September 2015), 1-15. https://doi.org/10.21009/PLPB.

[4] Depdiknas., Panduan Pengembangan Bahan Ajar. Jakarta: Departemen Pendidikan Nasional, 2008

[5] Dhewa, Merta., The Development of Higher Order Thinking Skill (Hots) Instrument Assessment In Physics Study. IOSR Journal of Research \& Method in Education (IOSR-JRME) Volume 7, Issue 1 Ver. $\mathrm{V}, 2017$

[6] Fanani. A, Dian. K, Pengembangan Pembelajaran Berbasis High Order Thinking di Sekolah Dasar. Jurnal Pendidikan Dasar, 2018

[7] Faturrohman, M., Model-Model Pembelajaran Inovatif; Yogyakarta, Ar-ruzz Media, 2015

[8] Gagne, R. M., The conditions of learning and theory of instruction New York: Holt. Rinehart and Winston, 1985.

[9] Muruganatham, G., Developing of E-Content Package by Using ADDIE Model. International Journal of Applied Research,I(3). 2015, 52-54

[10] Nugroho, R., HOT (Kemampuan Berpikir Tingkat Tinggi: Konsep, Pembelajaran, Penilaian dan SoalSoal). PT Gramedia Widiasarana Indonesia, 2018. 
[11] Pannen, P., Mengajar di Perdosenan Tinggi, buku empat, bagian "Pengembangan Bahan Ajar". Jakarta: PAU-PPAI, Universitas Terbuka, 1996

[12] Pratiwi D., Agil L., Pengembangan Bahan Ajar Berbasis Kontekstual Pada Mata Kuliah Biologi Umum, Jurnal Bioedukasi, 2015

[13] Prastowo, Panduan Kreatif Membuat Bahan Ajar Inovatif, Diva Press., 2011, hlm. 1

[14] Retnawati, H., Djidu, H., Kartianom, Apino, E., \& Anazifa, R. D., Teachers' knowledge about higherorder thinking skills and its learning strategy. Problems of Education in the 21st Century, 76(2), 2018, 215-230.

[15] Sani R., Pembelajaran Berbasisi Hot (high Order Thinking Skill). Tangerang. Tira Smart, 2019 